Iranian Quarterly Journal of Breast Disease. 2019; 12(1):19-28.
Receive: 2019/2/13

Accepted: $2019 / 4 / 23$

*Corresponding Author: Seyyed Reza Attarzadeh hosseini Attarzadeh@um.ac.ir

Ethics Approval: IR.MUM.FUM.REC.1397.038
Original Article

\section{Effect of Interval Training on the Expression of Mesenchymal Biomarker Vimentin and Tumor Volume in Mice with Breast Cancer}

\author{
Gholamian $\mathbf{S}^{1}$, Attarzadeh Hosseini $\mathbf{R}^{2^{*}}$, Rashidlamir $\mathbf{A}^{2}$, Aghaalinejad $\mathbf{H}^{3}$ \\ ${ }^{1}$ Ph.D. Student in Exercise physiology (Biochemistry and Metabolism), Faculty of \\ Sports Sciences, Ferdowsi University of Mashhad, Mashhad, Iran \\ ${ }^{2}$ Faculty of Sports Sciences, Ferdowsi University of Mashhad, Mashhad, Iran \\ ${ }^{3}$ Faculty of Humanities, Tarbiat Modares University, Tehran, Iran
}

\begin{abstract}
Introduction Many deaths from cancer are due to metastases, a process which involves the epithelial-mesenchymal transition (EMT). On the other hand, regular exercise plays an important role in inhibiting the progression of breast cancer. Therefore, the purpose of this study was to investigate the influence of interval training on the expression of VIM, the gene encoding for EMT biomarker vimentin, and tumor volume in mice with breast cancer.
\end{abstract}

Methods: Thirty-two female BALB/c mice were randomly divided into four groups: Exercise-Tumor-Exercise (ETE), Rest-Tumor-Rest (RTR), Rest-Tumor-Exercise (RTE), and Exercise-Tumor-Rest (ETR). Interval training was performed six weeks before and four weeks after the induction of 4T1 mammary carcinoma. The real-time PCR method was used to evaluate the expression of vimentin. Data were analyzed with one-way ANOVA followed by post hoc methods, considering a $\mathrm{P}$ value of $<0.05$ significant.

Results: Tumor tissue VIM expression in the ETE group decreased significantly $(\mathrm{P}<0.001, \mathrm{~F}=270.85)$, Also, a significant decrease in tumor volume was observed in both RTE and ETE groups compared to the control group (RTR) $(\mathrm{F}=23.81, \mathrm{P}<0.001)$.

Conclusion: Based on the results of this study, a period of interval training (before and after tumor) may decrease tumor growth and the expression of $V I M$. This kind of exercise can, in addition to the preventive role, may play a role in the treatment of breast cancer.

Keywords: Breast Cancer, Mesenchymal Biomarker, Vimentin, Interval Training, Tumor Volume 


\section{حجم تومور در موشهاى مبتلا به سرطان يستان}

سميرا غلاميان'، سيدرضا عطارزاده حسينى r*، امير رشيدلمير ‘، حميدآقاعلىنزاد ' دانشجوى دكترى فيزيولوزى ورزشى (بيوشيمى و متابوليسم)، دانشكده علوم ورزشى، دانشكاه فردوسى مشهد، مشهد،

مقدمه: بسيارى از مرگوميرهاى مبتلايان به سرطان ناشى از متاستاز است و فرايند درگير در

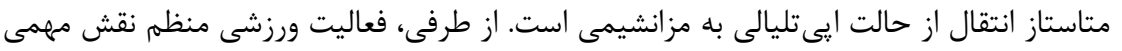

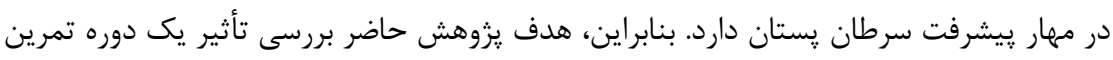

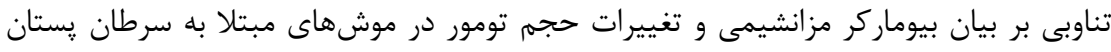

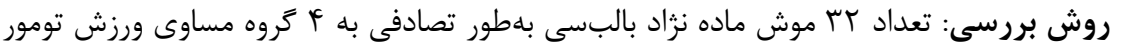

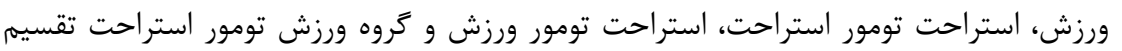

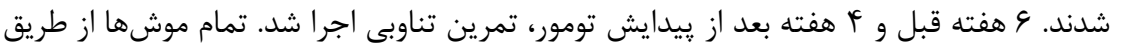

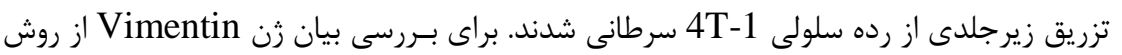
Real-Time PCR

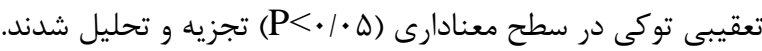

يافتهها: نتايج يزوهش حاضر نشان داد كه بيان زن Vimentin بافت تومور در زروه تمرين

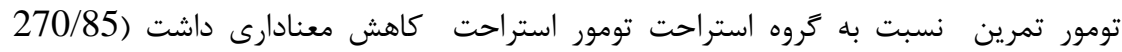

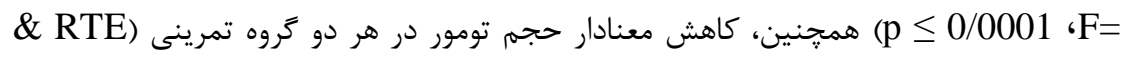

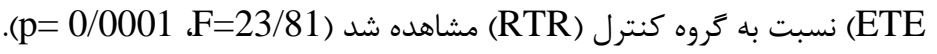

نتيجهَيرى: بر اساس نتايج يزوهش حاضر، يك دوره تمرين تناوبى (قبل و بعد از ريدايش

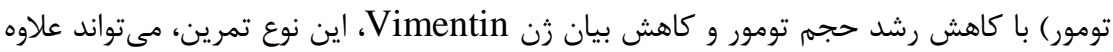

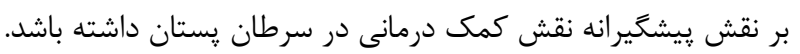
أوازههاى كليدى: سرطان يستان، بيوماركر مزانشيمى، Vimentin، تمرين تناوبى، حجم تومور 
سيستم ايمنى و رهايى مايوكاينها نقش مهمى در يشتَيرى از بروز بيمارىهاى التهابى از جمله سرطان

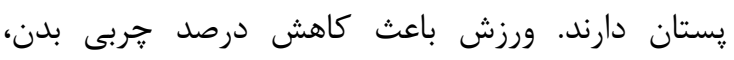

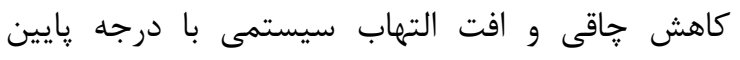

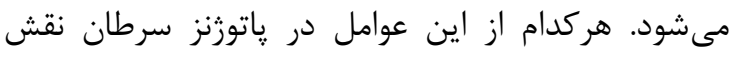

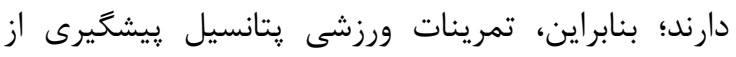

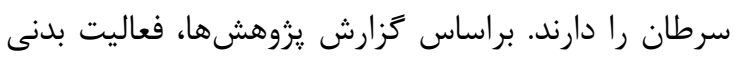

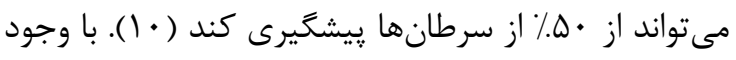

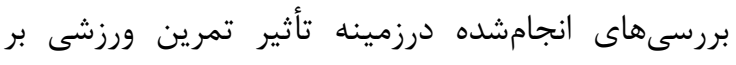

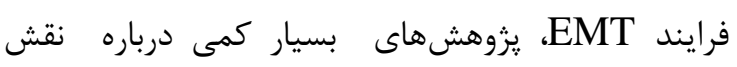

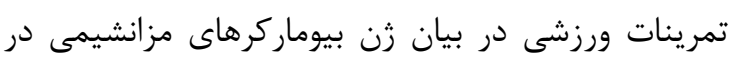

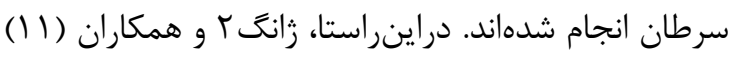

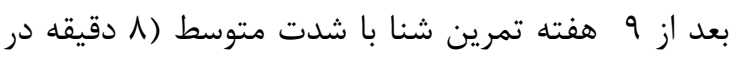

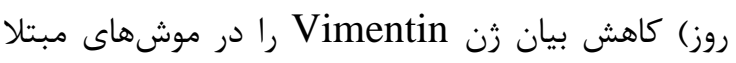
به سرطان كبد مشاهده كردند. آنها با تأكيد بر سيستم

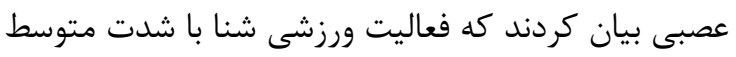

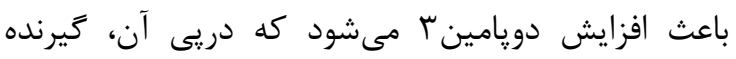
دويامين Tr Tr (كه داراى فعاليت ضدتومورى است) فعال مىشود و از اين طريق باعث سركوب فرايند

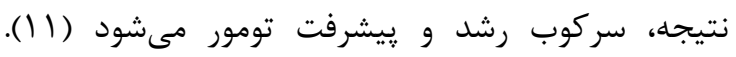

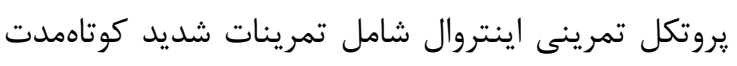

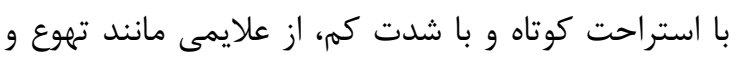

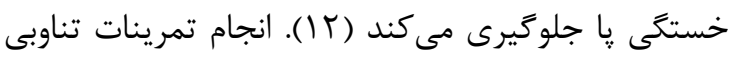

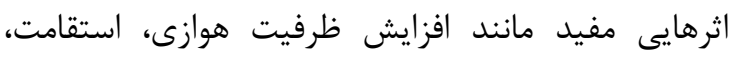

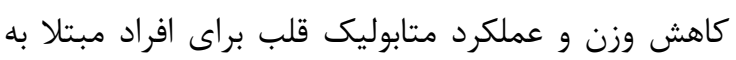

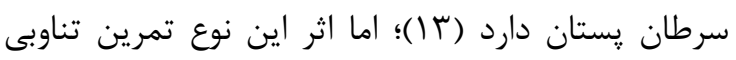

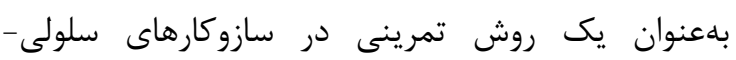

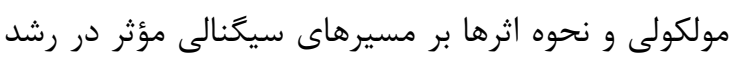

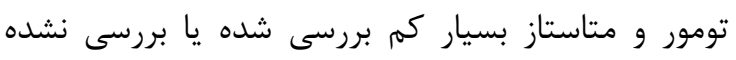

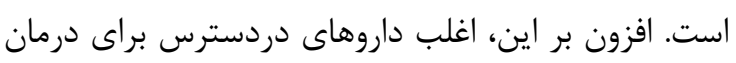
سرطان بهعلت تك هدف بودن، سمىبودن زياد، هزينه

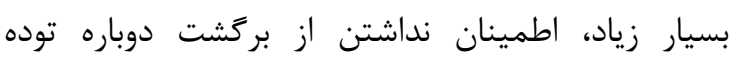

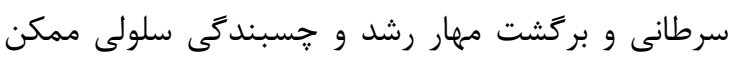

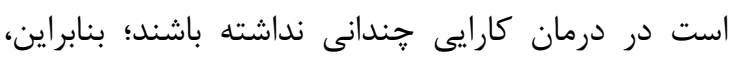

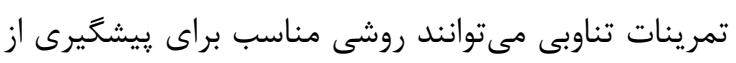
سرطان و در مراحل بعد، بخشى مهمه و حياتى از فرايند

\footnotetext{
${ }^{2}$ Zhang

${ }^{3}$ Dopamine

${ }^{4}$ Dopamine Receptor 2
} سرتاسر جهان است. عامل اصلى مرگ ناشى از سرطان ״يجֶيدگى هاى ناشى از متاستاز است (1). متاستاز رخداد

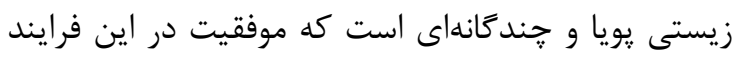
مستلزم آن است كه سلولهاى سرطانى توانايى جداشدن از سلولهاى مجاور را داشته باشند؛ بهطورى كه ماتريكس انس برونسلولى و غشاى يايه را هدف قرار دهند، وارد جريان خون شوند و سرانجام به بافتهاى دورتر وارد شوند.

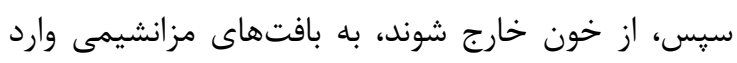

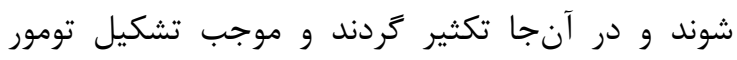
ثانويه در آن محل شوند. در واقع، اين فرايند مسئول كسترش ميزان شيوع و مرگومير ناشى از سرطان است.

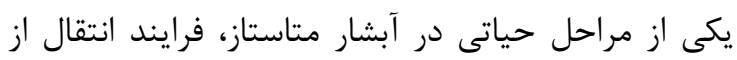
حالت ايىتليالى به حالت مزانشيمى يا همان

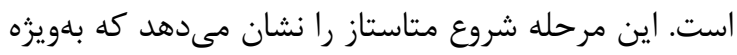

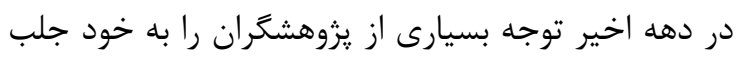

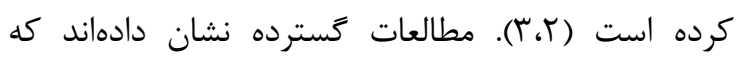
EMT

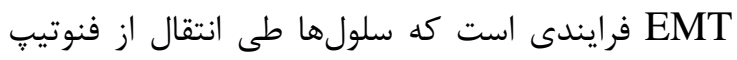
إيىتليالى به فنوتيتٍ مزانشيمى، با تهاجم و تحرك بيشتر

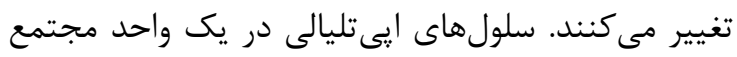
سازماندهى مىشوند و با ازدستدادن يروتئينهاى اتصال

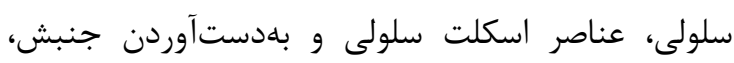
كادهرينهاى مزانشيمى به سلولهاى مزانشيمال تبديل مىشوند (ه). مراحل EMT با يك سرى عوامل رونويسى مريى تنظيم مىشوند كه ازجمله آنها Vimentin است (Q) (؟).

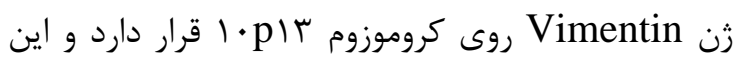
يروتئين \&\& ينكى از : يروتئينهاى اصلى روى غشا

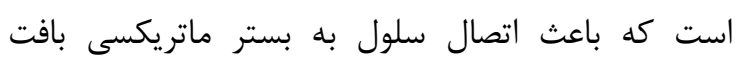

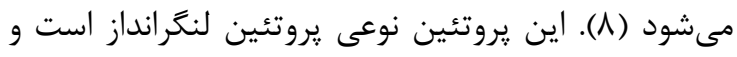

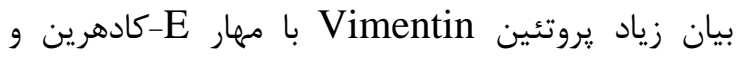
القاى EMT، باعث افزايش توانايى تهاجم و متاستاز سلولهاى سرطانى مىشود (9)؛ بر اين اساس، اخيراً بهعنوان يـك هـدف بـراى درمان سرطان درنظر كرفته شده اسـت (V). تمرينات بدنى با شدت متوسط، با تقويت

\footnotetext{
${ }^{1}$ Epithelial to Mesenchymal Transition
} 
يستان است كه توانايى متاستاز مؤثر به نواحىاى را دارد

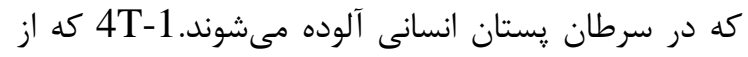

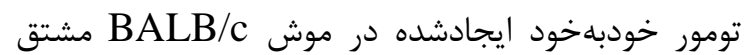

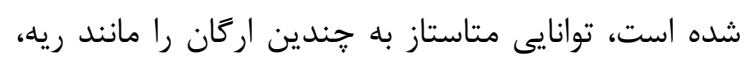

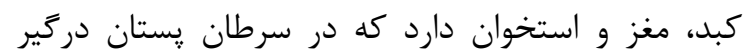
مىشوند (ه ا). در اين يروهش، سلول

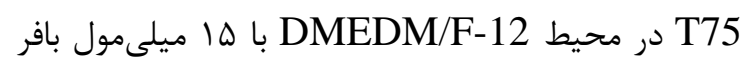

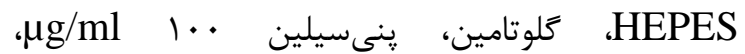

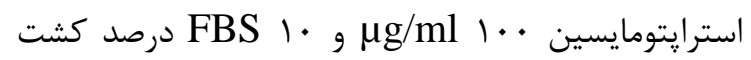
داده شد. يس از آنكه سلولها بها به اندازه موردنياز در محيط

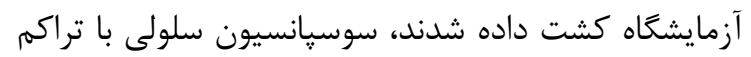

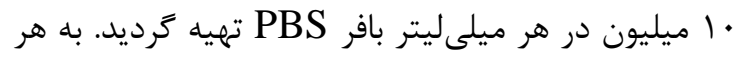
موش يك ميليون سلول بلهورت زيرجلدى و متمركز به

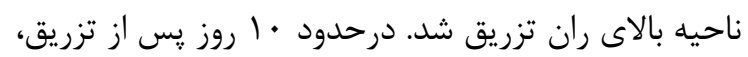

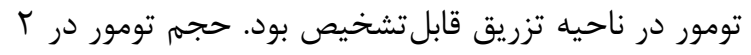

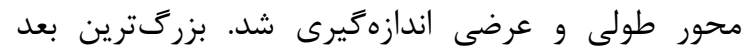

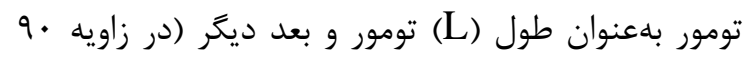

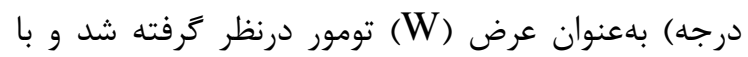

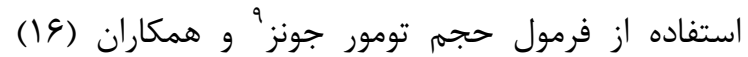

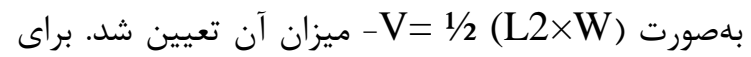

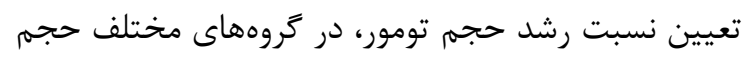
تومور هفته جهارم به هفته اول تقسيم شد. توند

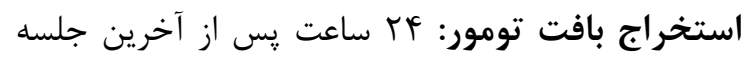
تمرين، موشهاى تومورى از تمامى گروهها از طريق تزريق آريق

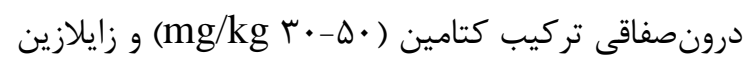

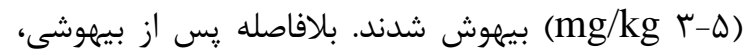

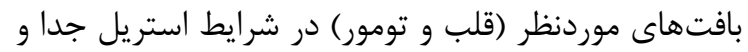
وزن شدند. سيس، بافت موردنظر در نيتروثن مايع منجمد

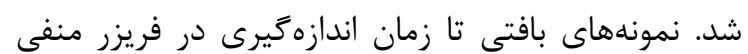

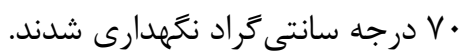

استخراج RNA و سنتز

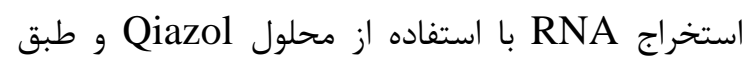

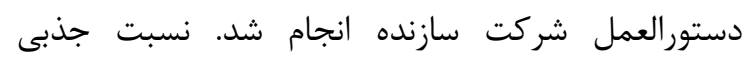

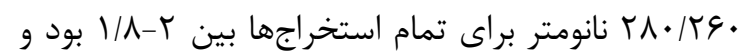

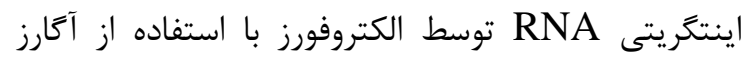
ايتديوم برمايد (ا درصد) سنجيده شد.

${ }^{9}$ Jones
درمان اين بيمارى باشند. مطالعه EMT بهدليل ييجيدگى گستردگى دشوار است و با קالشهايى همراه

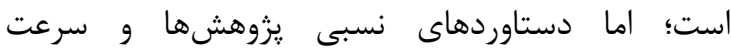
خيرهكننده آنها اين نويد را مى دهد كه مطالعه جزئيات

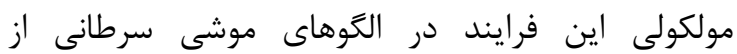
محورهاى اصلى يزوهشهاى آينده خواهد بود؛ بنابراين،

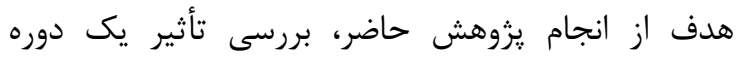

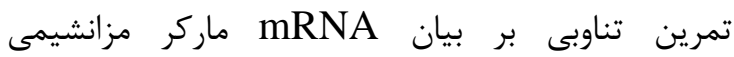
Vimentin

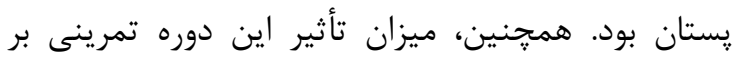

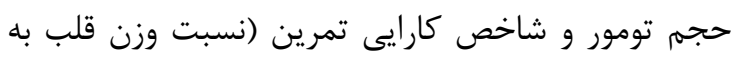

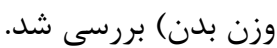

\section{مواد و روشها}

يزوهش حاضر ازنوع تجربى و بنيادى بود كه به شيوه

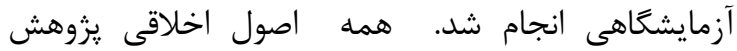

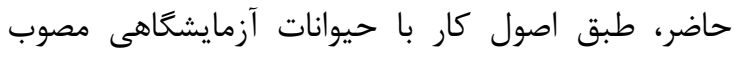

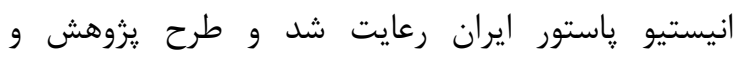

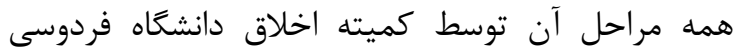
(IR.MUM.FUM.REC.1397.038) تأييد شد. در اين مطالعه، rr موش ماده نزاد Balb/c

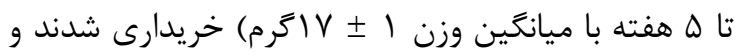

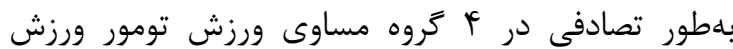
(ETE)

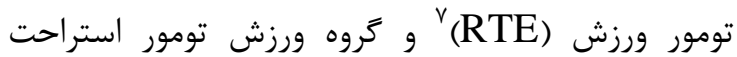

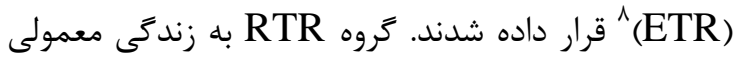

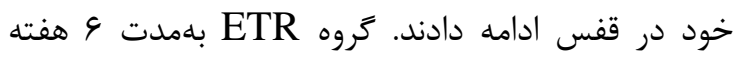

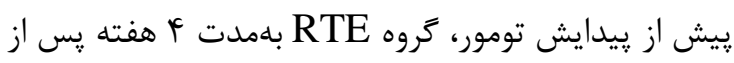

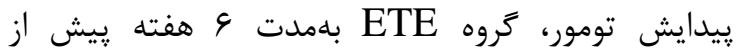

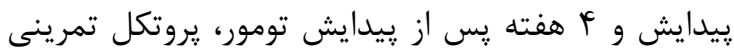

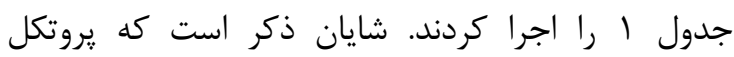

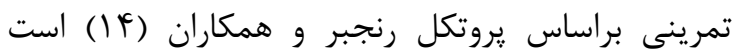

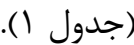
كشت سلول: تومور مورد مطالعه از رده سلولى

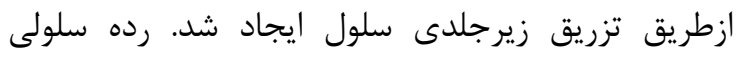

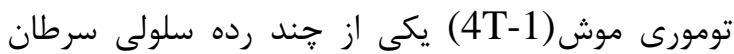

\footnotetext{
${ }^{5}$ Exercise-Tumor-Exercise

${ }^{6}$ Rest-Tumor-Rest

${ }^{7}$ Rest-Tumor-Exercise

${ }^{8}$ Exercise-Tumor-Rest
} 


\begin{tabular}{|c|c|c|c|c|c|c|}
\hline \multicolumn{7}{|c|}{ جدول ا: بروتكل تمرينى } \\
\hline تكرار (روز در هفته) & كل زمان (دقيقه) & زمان (دقيقه) & تكرار & سرعت (متر در دقيقه) & شرايط ورزش & دوره تمرين \\
\hline$r$ & 1. & - & - & $|r|$. & قبل از القاى تومور & مرحله آشناسازى \\
\hline$\Delta$ & r. & r & $r \cdot$ & $r \cdot g 10$ & قبل از القاى تومور & هفته هاى اول و دوم \\
\hline$\Delta$ & r. & r & $r \cdot$ & $r \Delta, r \cdot$ & قبل از القاى تومور & هفتههاى سوم و جههارم \\
\hline$\Delta$ & f. & r & $r \cdot$ & $r \cdot g, r \Delta$ & قبل از القاى تومور & هفتههاى ينجم و ششم \\
\hline \multicolumn{7}{|c|}{ تمرين بعد از القاى تومور } \\
\hline$\Delta$ & $r \cdot$ & r & 10 & $r \cdot g, T \Delta$ & بعد از القاى تومور & هفته هفتم \\
\hline$\Delta$ & $r \cdot$ & r & 10 & $r \cdot g \Delta$ & بعد از القاى تومور & هفته هشتم \\
\hline & $r \cdot$ & $r$ & 10 & $r \cdot g 10$ & بعد از القاى تومور & هفته نهم \\
\hline$\Delta$ & $r \cdot$ & r & 10 & $\mid 0,1$. & بعد از القاى تومور & هفته دهم \\
\hline
\end{tabular}

جدول r: توالى : برايمرها

\begin{tabular}{ccc}
\hline آغازكر برگشتى & \multicolumn{1}{c}{ آغازگر جلويى } \\
\hline Vimentin & ACATCATACGGCTGCGAGAG & GACTTGCTGTTCCTGAATCTGG \\
ACTB & GGCTGTATTCCCCTCCATCG & CCAGTTGGTAACAATGCCATGT \\
\hline
\end{tabular}

بCTB

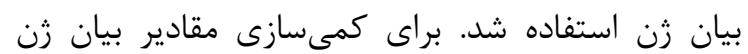
موردنظر از فرمول روشهاى آمارى: براى بررسى طبيعى بودن توزيع

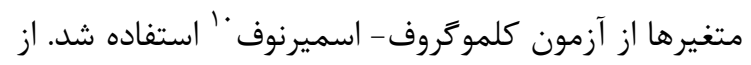

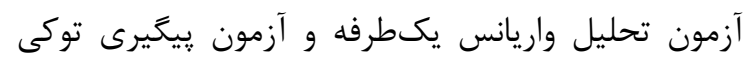
نيز براى تحليل دادهها اسـتفاده شد. تمام عمليات آمارى آنسي

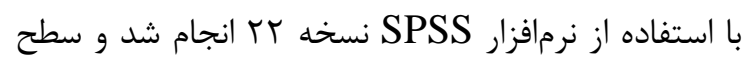
معنادارى (ه • P (P) در نظر كرفته شد.

\section{كافتهها}

اثر تمرين تناوبى بر بيان زن Vimentin بافت

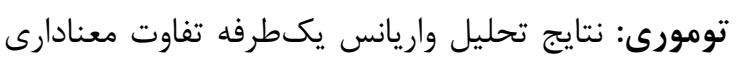

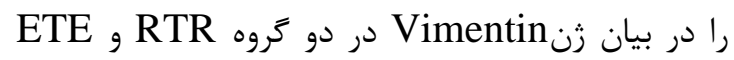

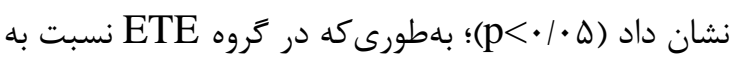

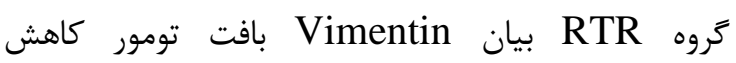

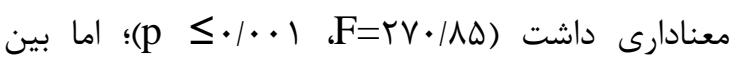
كروهاى RTE

$$
\text { معنادارى وجود نداشت (نمودار ()). }
$$

اثر تمرين تناوبى بر حجم تومور: نشان داد كه نسبت

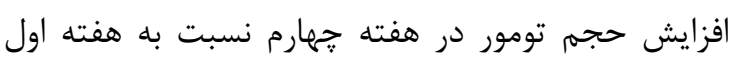

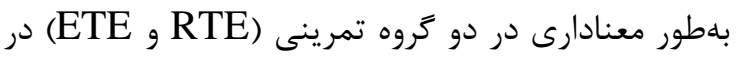

\footnotetext{
${ }^{10}$ Kolmogorov-Smirnov Test
}

براى رونويسى RNA به RNA از كيت PrimerScript RT Regent Takara Japan

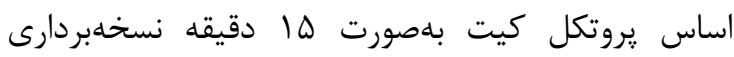

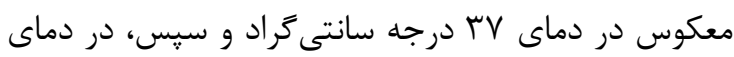

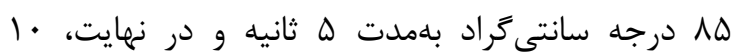

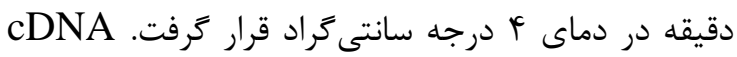

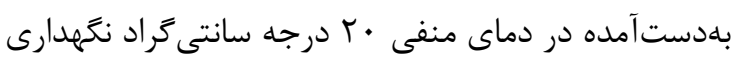

شد.

مراحل انجام Real Time PCR: با استفاده از Stepone plus(Applied Biosystems) دستخاه براساس SYBER-Green از كيت، Perfect Takara Realtime g code RR041A Japan دستورالعمل كيت انجام شد. يرايمرهاى استفاده شده در

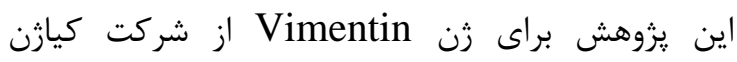
خريدارى شدند (مشخصات يرايمر در جدول بر ب). يروفايل

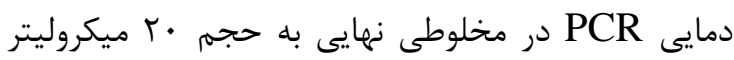

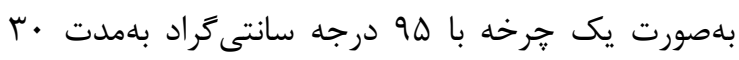

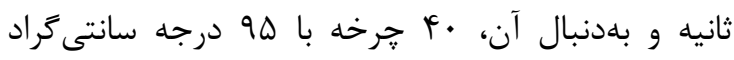

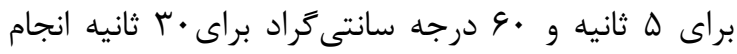

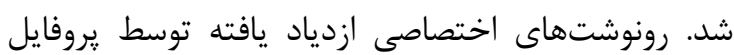

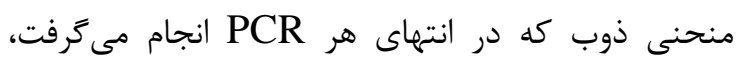
تصديق شدند. طراحى توالى يرايمرها توسط نرمافزار Runner Gene 

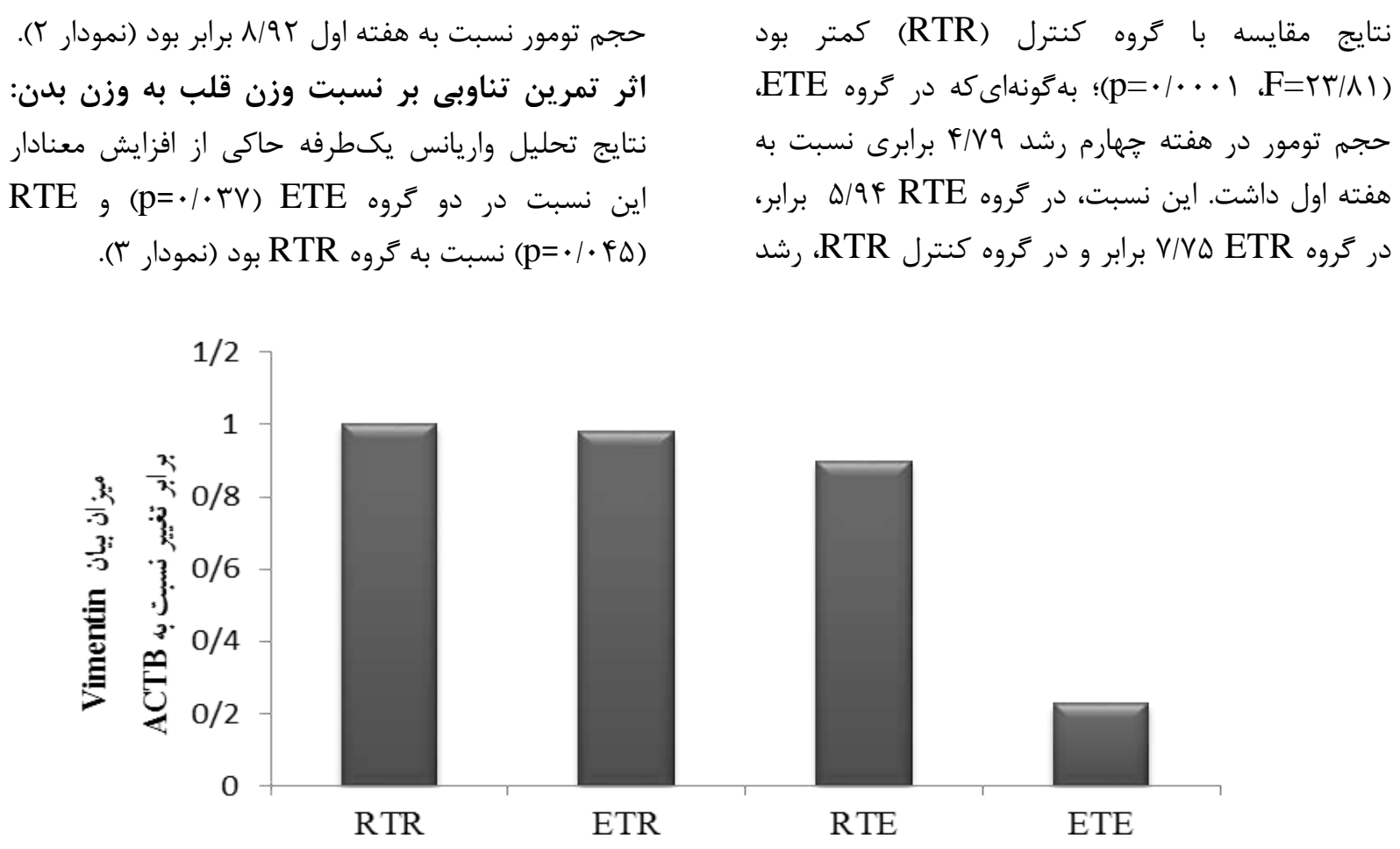

نمودار ا: تغييرات بيان زن Vimentin در كروههاى يخوهش (برابر تغيير نسبت به كروه كنترل)

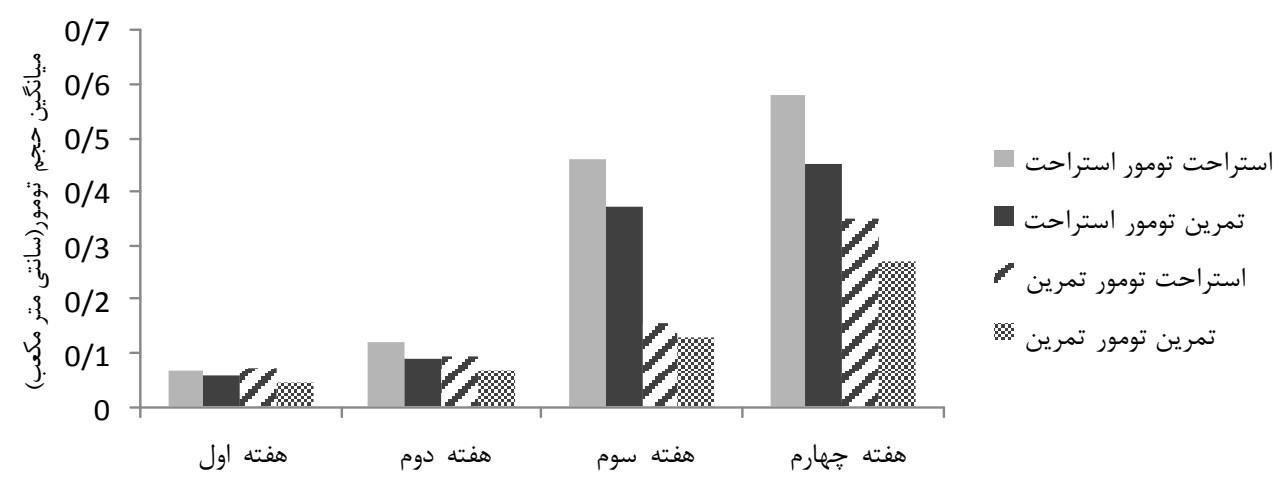

نمودار r: مقايسه حجم تومور در \& هفته بعد از سرطانىشدن در تروههاى مختلف يزوهش

Mean heart/Mean weight

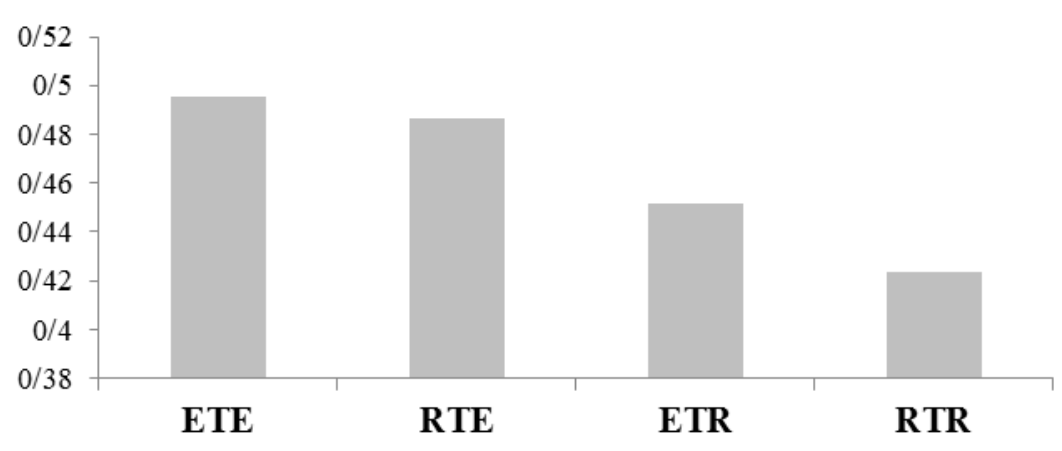

نمودار با: مقايسه نسبت وزن قلب به وزن بدن موشها در F عروه 
همجنين، IL-6 ازطريق سيحنالينگ القاى EMT است (Iآ). در گروهى از افراد مبتلا به سرطان يستان با گيرنده هورمون استروزن مثبت،

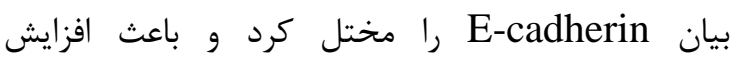
شد (Trimentin برخى فعاليتهاى ورزشى سبب كاهش سايتوكاينهاى

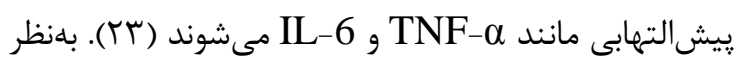
مىرسد كه ورزش ازطريق عوامل زيادى از قبيل اثركذارى مانئن بر مسير JAK/STAT3 مى Jواند به كاهش تومورى و بيان STAT3 منجر شود و درنتيجه، از اين مسير سبب كاهش تكثير سلولى، تغيير شكل سلولى،

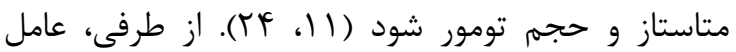
تومور بهعنوان يك استرس برونسلولى سبب افزايش بيان

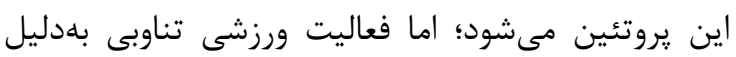
ماهيت متفاوت خود؛ يعنى وجود وهلههاى استراحتى بين مراحل تمرينى، برخلاف تمرين ييوسته از افزايش مداوم و

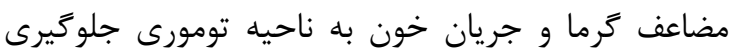
مى كند و در اين نوع فعاليت برخلاف فعاليت بيوسته استرس كمترى در ناحيه تومور ايجاد مىشود كه شايد يكى از اين دلايل كاهش اين يروتئين و حجمم تومور باشد.

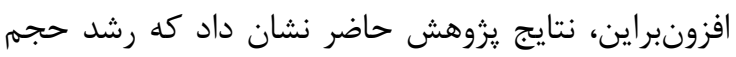

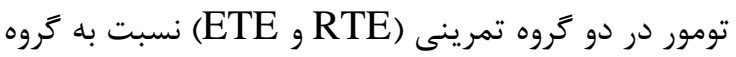

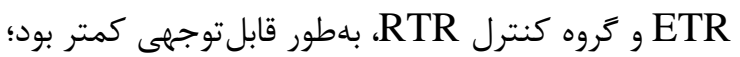
به گونهاى كه در گروه ETE، حجم تومور در هفته جهارم رشد F/V9 برابرى نسبت به هفته اول داشت. اين نسبت،

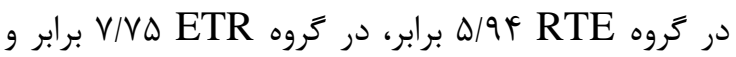
در گروه كنترل RTR رشد حجم تومور نسبت به هفته درو

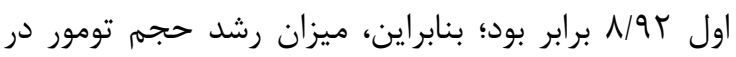

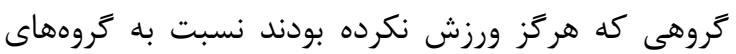
ديخر بيشتر بود. همجنين در نتايج يزوهش حاضر مشخص شد كه در دو گروه ETR و ETE سرطانى شدن \& هفته تمرين تناوبى اجرا كردند نسبت به دوره گروه كنترل RTR كه هيجزونه تمرين تناوبى نداشتند، نسبت حجم تومور كمتر است.كه اين نتايج نشان مى دهد

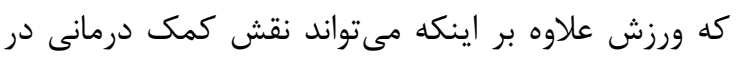
سرطان داشته باشد، نقش ييشخيرانه نيز در سرطان دارد.

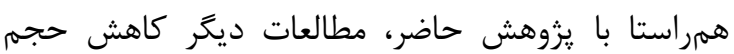

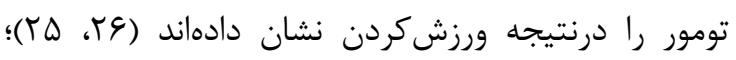

\footnotetext{
${ }^{14}$ Janus Kinase
}

\section{بحث}

در يزوهش حاضر، تأثير تمرينات تناوبى بر تغييرات حجم

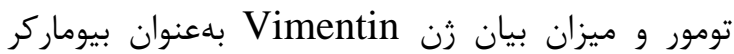

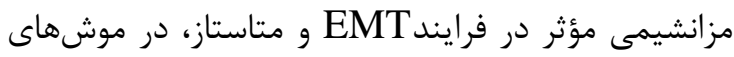

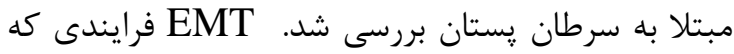

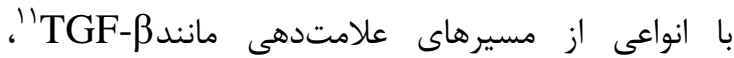

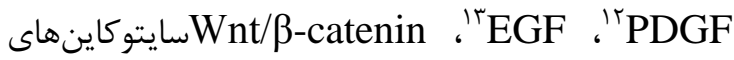
ييشالتهابى IL-8 و IL-6 ،

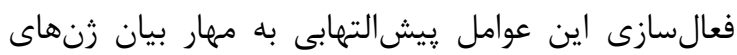

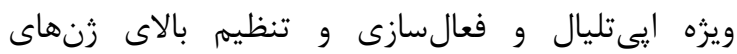

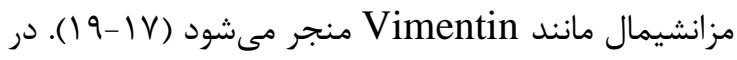

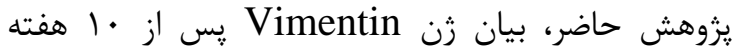

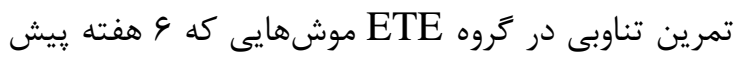
از تومورىشدن و أ هفته يس از تومورىشدن تمرين

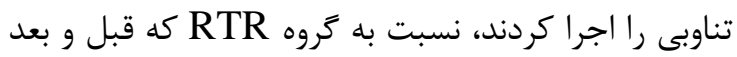

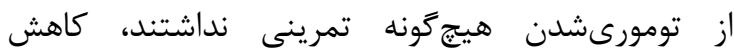

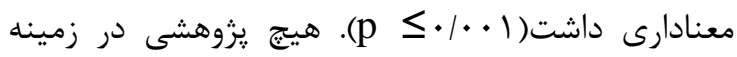

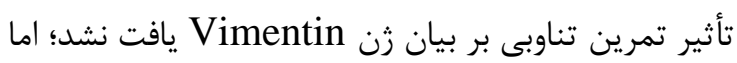

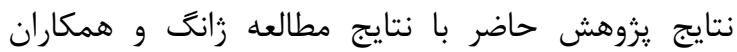
همخوانى داشت. آنها اظهار كردند كه تمرين شنا بهمدت بـات 9 هفته با شدت متوسط (1 دقيقه در روز) باعث كاهش بيان زن Vimentin و حجم تومور در موشهاى مبتلا به سرطان كبد مىشود (1). سازوكار تأثيرگذارى تمرينات

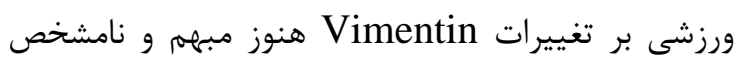

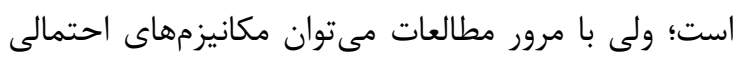

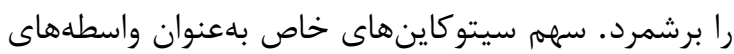
التهابى EMT بهطور كستردهاى در مطالعات بيان شده است كه مهرمترين آنها TGFسايتوكاين ييشالتهابى در جريان بيشرفت فرايند EMT

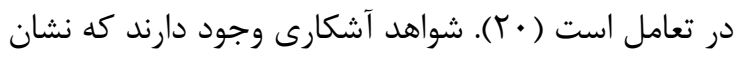

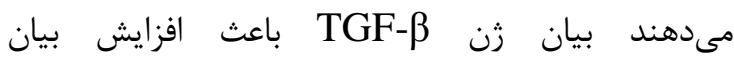

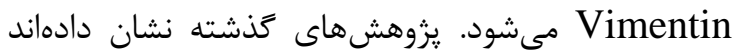
كه تمرين مىتواند باعث كاهش بيان TGFبنابراين، فعاليت بدنى منظم مى تواند ازطريق مهار مسير بـاني سيخنالينغ TGFمزانشيمى سينينك

\footnotetext{
${ }^{11}$ Transforming Growth Factor- $\beta$

${ }^{12}$ Derived Growth Factor

${ }^{13}$ Epidermal Growth Factor
} 
موشها محاسبه شد كه نتايج افزايش معنادار اين نسبت را

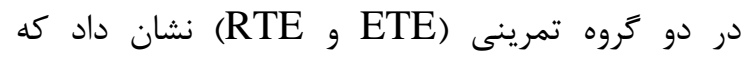

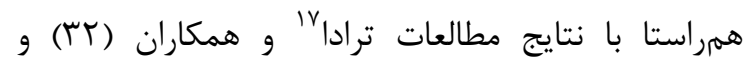

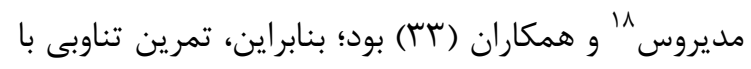

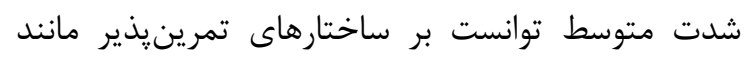

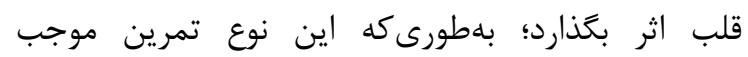

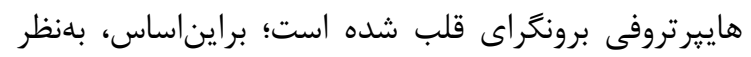

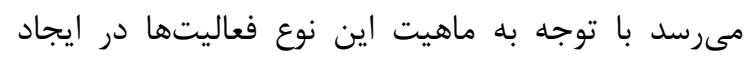

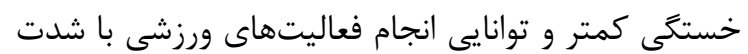

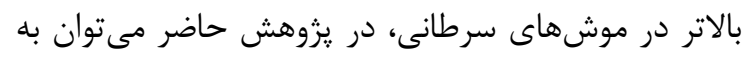

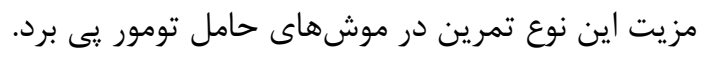

\section{نتيجهكيرى}

بر اساس نتايج يروهش حاضر، يك دوره تمرين تناوبى (قبل و بعد از ييدايش تومور) با كاهش رشد حجم تومور و

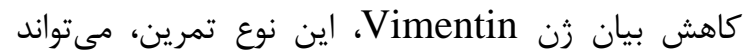
علاوه بر نقش بيشخيرانه نقش كمك درمانى در سرطان

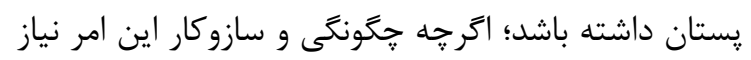

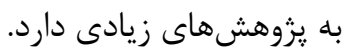

\section{تعارض منافع}

نويسندكان اعلام مى دارند كه هيج تعارض منافعى در ئزوهش حاضر وجود ندارد.
زيلينسكى ها و همكاران (YV) كاهش و تأخير رشد تومور

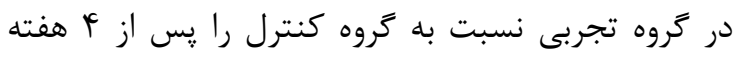
تمرين استقامتى به كاهش ميزان سلولهاى ايمنى در

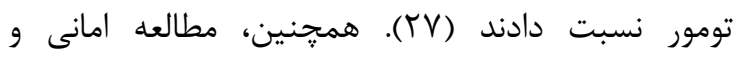
همكاران (YN) نشاندهنده كاهش حجم تومور و ركزايى

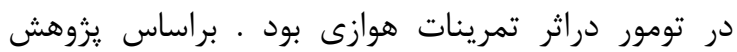

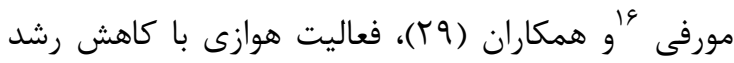
حجم تومور ييشرفت تومور را در گروه تمرين نسبت به

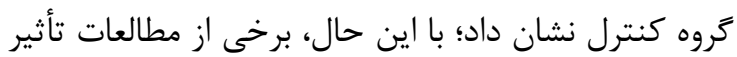
نداشتن تمرينات ورزشى بر تغييرات حجم تومور را نشان

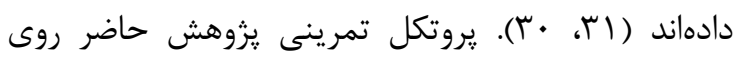

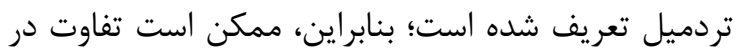
شيوه تمرينى، طول دوره تمرينى و نوع تومور القاشده

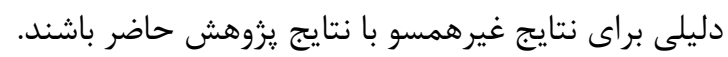

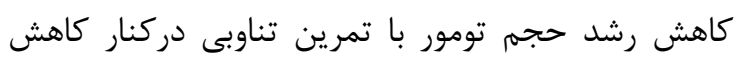

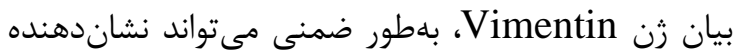

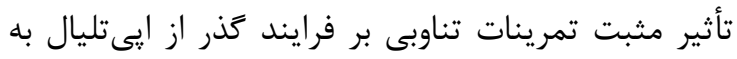
مزانشميال در موشهاى مبتلا به سرطان يستان باشد. شايان ذكر است كه يروهشهاى بسيار كمى درزمينه

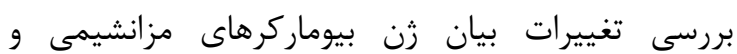

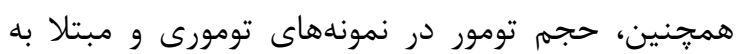

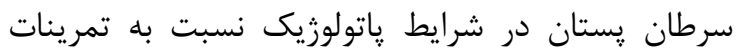

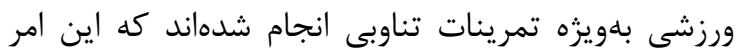

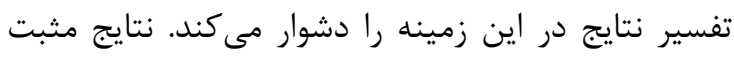
نشان مىدهد كه ممكن است فرايندهايى مانند كاهش خونرسانى به سلولهاى تومورى در كاهش رشد تومور دخيل باشند؛ البته با توجه به اينكه عوامل مؤثر در فرايند

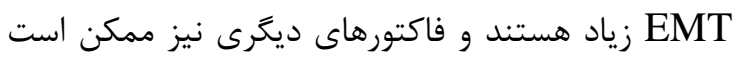

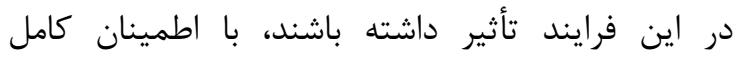

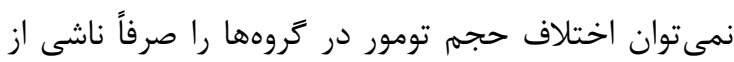

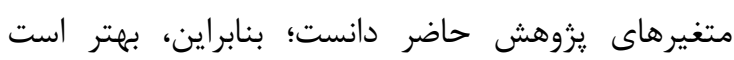

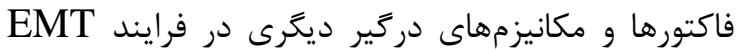

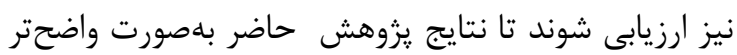

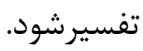

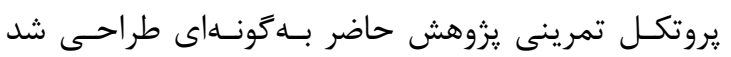

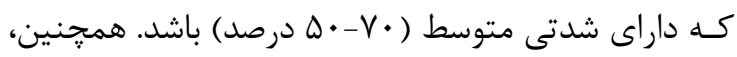

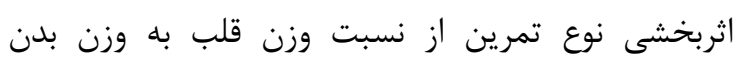

\footnotetext{
${ }^{15}$ Zielinski

${ }^{16}$ Murphy
} 


\section{References}

1. Vaidya KS, Welch DR. Metastasis suppressors and their roles in breast carcinoma. J Mammary Gland Biol Neoplasia. 2007;12(2-3):175-90.

2. MR ND, Fazilaty H, Tabrizi M. Cancer metastasis, genetic and microenvironmental factors of distant tissue: A review article. Tehran University Med Sci. 2013;70(11):1370.

3. Chai J, Modak C, Mouazzen W, Narvaez R, Pham J. Epithelial or mesenchymal: Where to draw the line? Biosci trends. 2010;4(3):130-42.

4. Kalluri R, Neilson E. Epithelial-mesenchymal transition and its implications for fibrosis. JClin Invest. 2003; 112(12):1776-84.

5. Kalcheim C. Epithelial- mesenchymal transitions during neural crest and somite development. J Clin Med. 2015;5(1):716-25.

6. Kalluri R, Weinberg RA. The basics of epithelial-mesenchymal transition. J Clin Invest. 2010;120(5): 1786.

7. Satelli A, Li S. Vimentin in cancer and its potential as a molecular target for cancer therapy. Cell Mol Life Sci. 2011;68(18):303346.

8. Wu Y, Zhang X, Salmon M, Lin X, Zehner ZE. TGFbeta1 regulation of vimentin gene expression during differentiation of the $\mathrm{C} 2 \mathrm{C} 12$ skeletal myogenic cell line requires Smads, AP-1 and Sp1 family members. Biochimica et Biophysica Acta (BBA). 2007;1773(3):427-39.

9. Hwangbo C, Tae N, Lee S, Kim O, Park O, Kim J, et al. Syntenin regulates TGF- $\beta 1$ induced Smad activation and the epithelial-tomesenchymal transition by inhibiting caveolinmediated TGF- $\beta$ type I receptor internalization. Oncogene. 2016;35(3):83-9.

10. LEE I-M. Physical activity and cancer prevention-data from epidemiologic studies. MedSci Sports Exerc. 2003;35(11):1823-27.

11. Zhang L, Liu W, Gao Y, Qin Y, Wu R. The expression of IL-6 and STAT3 might predict progression and unfavorable prognosis in Wilms' tumor. Biochem Biophys Res Commun. 2013;435(3):408-13.

12. Gibala MJ, Little JP, MacDonald MJ, Hawley JA. Physiological adaptations to low-volume, high-intensity interval training in health and disease. J physiol. 2012;590(5): 1077-84.

13. Meyer K, Samek L, Schwaibold M, Westbrook S, Hajric R, Lehmann M, et al. Physical responses to different modes of interval exercise in patients with chronic heart failure: Application to exercise training. Eur Heart J. 1996;17(7):1040-7.

14. Ranjbar K, Agha Alinejad H, Shahbazi SH, Molanouri Shamsi SH. Interval aerobic exercise and selenium nanoparticle stimulate autophagy in mice with cancer cachexia .Int $\mathbf{J}$ Cancer Oncol. 2018;5(1):35-40.

15. Baliga MS, Meleth S, Katiyar SK. Growth inhibitory and antimetastatic effect of green tea polyphenols on metastasis-specific mouse mammary carcinoma 4T1cells invitro and invivo systems. Clin Cancer Res. 2005;11(5):1918-27.

16. Jones L, Viglianti B, Tashjian J, Kothadia S, Keir S, Freedland S, et al. Effect of aerobic exercise on tumor physiology in an animal model of human breast cancer. J Appl Physiol. 2009;108(2):343-8.

17. Thiery J, Sleeman J. Complex networks orchestrate epithelial mesenchymal transitions. Nat Rev Mol Cell Biol. 2006;7(2):131-42.

18. Palena C, Hamilton D, Fernando R. Influence of IL-8 on the epithelial mesenchymal transition and the tumor microenvironment. Future Oncol. 2012; $8(6): 713-22$

19. Yuji T, Hiromi Y, Susumu S,Koji T, Yasuhiro I, Ajay G, Masato K. Increased expression of Slug and Vimentin as novel predictive biomarkers for lymph node metastasis and poor prognosis in colorectal cancer. Carcinogenesis. 2013;34(11):2548-57.

20. Massague J. TGFbeta in Cancer. Cell. 2008;134(2):215-30.

21. Hunter C, Jones S. IL-6 as a keystone cytokine in health and disease. Nat Immunol. 2015;16(5): 448-57.

22. Sullivan N, Sasser A, Axel A, Vesuna F, Raman V, Ramirez N, et al. Interleukin-6 induces an epithelial-mesenchymal transition phenotype in human breast cancer cells. Oncogene. 2009; 28(33):2940-7.

23. Suzuki K, Nakaji S, Yamada M, Totsuka M, Sato K, Sugawara K. Systemic inflammatory response to exhaustive exercise. Cytokine kinetics. Exerc Immunol Rev. 2002;8(1):46-8.

24. Jiang S, Zhang HW, Lu MH, He XH, Li Y, $\mathrm{Gu} \mathrm{H}$, et al. MicroRNA-155 functions as an OncomiR in breast cancer by targeting the suppressor of cytokine signaling 1 gene.Cancer Res. 2010;70(8):3119-27.

25. Friedenreich C, Orenstein M. Physical activity and cancer prevention: Etiologic 
evidence and biological mechanisms. J Nutr. 2002;132(11):3456-64.

26. Liu $\mathrm{X}$, Chu $\mathrm{K}$.E-cadherin and gastric cancer: Cause, consequence, and applications. BioMed Res Int. 2014;12(1):9.

27. Zielinski MR, Muenchow M, Wallig MA, Horn PL, Woods JA. Exercise delays allogeneic tumor growth and reduces intratumoral inflammation and vascularization. J Appl Physiol. 2004;96(6):2249-56.

28. Amani-shalamzari S, Agha-Alinejad H, Alizadeh S, Shahbazi S, Khatib Z K, Kazemi A, et al. The effect of exercise training on the level of tissue IL-6 and vascular endothelial growth factor in breast cancer bearing mice. Iran J Basic Med Sci. 2014;17(4):231-6.

29. Murphy EA, Davis JM, Barrilleaux T, McClellan J, Steiner J, Carmichael M, et al. Benefits of exercise training on breast cancer progression and inflammation in $\mathrm{C} 3$ (1) SV40Tag mice. Cytokine. 2011;55(2):274-9.
30. Betof AS, Dewhirst MW, Jones LW. Effects and potential mechanisms of exercise training on cancer progression: A translational perspective. Brain, behavior, and immunity. 2013;30(15):75-8.

31. Woods JA, Vieira VJ, Keylock KT. Exercise, inflammation, and innate immunity Immunology and allergy. Phys Med Rehabil Clin. 2009; 29(2):381-93.

32. Terada S, Tabata I, Higuchi M. Effect of high intensity intermittent swimming training of fatty acid oxidation enzyme activity in rat skeletal muscle. Japanese $\mathbf{J}$ of Physiol. 2004;54(1): 47-52.

33. Medeiros A, Oliveira Em, Gianolla R, Casarini D, Negrao C, Brum P. Swimming training increase cardiac vagal activity and induces cardiac hypertrophy in rats. Brazilian. J of Med Biol Research. 2004;37(12):1909-17. 